Мулик Л. I.

ORCID ID: 0000-0002-9763-2738

Солнцев С. $\mathrm{O}$.

доктор фіз-мат наук, професор

ORCID ID: 0000-0002-8820-3528

Національний технічний університет Украйни «КПІ імені Ігоря Сікорського»

\title{
МАРКЕТИНГ НЕЗАЛЕЖНИХ ТА АФІЛІЙОВАНИХ СТАРТАПІВ
}

\section{МАРКЕТИНГ НЕЗАВИСИМЫХ И АФФИЛИРОВАННЫХ СТАРТАПОВ}

\section{MARKETING OF INDEPENDENT AND AFFILIATED STARTUPS}

У статті визначено основні складові діяльності стартап-проектів, щзо включають наявність інновачійної ідеї, інтелектуальні та фінансові ресурси та маркетинг інновацій. Систематизовано підходи вчених до визначення етапів розвитку стартапів $i$ проаналізовано найбільш використовувані з них. Окреслено специфіку етапів розвитку незалежних та афілійованих стартапів, проведено їх порівняльний аналіз, $і$ як результат, розкрито відмінності в етапах, їх послідовності та маркетинговій діяльності незалежних та афілійованих стартапів, серед яких зокрема наступні: різні етапи та напрямки розвитку проектів, изільові аудиторії на кожному з етапів діяльності стартапу, джерела фінансування; різняться принщипи формування команди та інститути, щзо повинні бути задіяні при розробці та виведенні продукту на ринок, відповідно відрізняються канали збуту та комунікацій, щзо використовуються компаніями. На основі детального аналізу вище зазначених питань в статті наведено маркетингові дї на кожному із етапів розвитку стартап-проектів інноваційної продукиії.

Ключові слова: стартап, поняття стартапу, бізнес-модель, маркетинг стартапів, інновації, маркетинговий аналіз, інвестиції, комерціалізація.

В статье определены основные составляющие деятельности стартап-проектов: наличие инновачионной идеи, интеллектуальные и финансовые ресурсы, а также маркетинг инновачий. Систематизировань подходы ученьх $\kappa$ определению этапов развития стартапов и проанализированы наиболее используемые из них. Определена специфика этапов развития независимых и аффилированных стартапов; проведен их сравнительный анализ $u$, как результат, раскрыты различия в этапах, их последовательности $u$ маркетинговой деятельности независимых и аффилированных стартапов. Среди отличий, в частности были выделены следуюшие: различные этапы и направления развития проектов, иелевые аудитории на каждом из этапов деятельности стартапа, источники финансирования, различаются приниипь формирования команды и институты, которые должны быть задействованы при разработке $и$ выведении продукта на рынок, соответственно отличаются каналь сбыта и коммуникачий, используемые компаниями. На основе детального анализа вышеуказанных вопросов, в статье приведены маркетинговые действия на каждом из этапов развития стартап-проектов инновационной продукиии.

Ключевые слова: стартап, понятие стартапа, бизнес-модель, маркетинг стартапов, инновации, маркетинговый анализ, инвестиции, коммерциализация.

The article identifies the main components of the activities of start-up projects: availability of innovative ideas, intellectual and financial resources, as well as the marketing of innovations. Were studied scientific papers devoted to the determination of the development stages of a startup. We analyzed the most used ones, the specifics of stages in the development of independent and affiliated startups. We carried out a comparative analysis and, as a result, revealed differences in 
the stages, their sequence and marketing activities of independent and affiliated startups. Among the differences, in particular, highlighted the following: the different stages and directions of development projects; audiences at every stage of operations startup; sources of funding; different principles of formation of the team and institutions that should be involved in the development and excretion of the product on the market; respectively different marketing and communication channels used by companies. Based on a detailed analysis of the issues in the articles were defined marketing activities at each stage of the development of start-up projects of innovative products.

Key words: startup, startup concept, business model, marketing of startups, innovation, marketing analysis, investment, commercialization.

Вступ. Сьогодні в ситуації безперервних змін умов функціонування ринків, великі корпорації не встигають за мінливістю споживчих вподобань. Як наслідок почали виникати нові форми бізнесу 3 точки зору втілення інноваційних ідей - стартапи. Проте статистика успішності стартапів показує, що близько 90\% із них завершує діяльність уже в перший рік після виходу на ринок, що $\epsilon$ результатом як недосконалості продукту, так i відсутністю методології для маркетингових дій на кожному із етапів стартап-проектів.

Дослідженням діяльності стартапів займались як зарубіжні, так і вітчизняні вчені, а також бізнесмени, які починали власну діяльність із заснування стартапу. Найбільш відомими є праці таких науковців як Бланк С., Райнер Л., Ріс Е., Грехем П., Пітер Т., Дорф Б., Вонг Д., Бучацький Е., Казнок Б., Пономарев Д., Корнух О. В., Свсейчев А. І., Каширин А. І., Пікуль В. С., Мрихіна О. Б. і т. д. Авторів які досліджують специфіку діяльності стартапів багато, проте маркетингові засади стартап-проектів є недостатньо розкритими, що підтверджує актуальність дослідження.

Постановка завдання. Метою статті $є$ аналіз етапів діяльності стартапів, визначення специфіки роботи та маркетингової діяльності незалежних на афілійованих стартапів на кожному із етапів їх розвитку.

Методологія. За теоретичну основу дослідження було взято напрацювання вітчизняних та зарубіжних науковців у сфері маркетингу стартапів, що вивчали специфіку їх становлення та розвитку. Теоретикометодологічною базою дослідження $є$ загальнонаукові та спеціальні методи систематизації, синтезу, методи утворення бізнес моделей. Інформаційною базою дослідження є матеріали періодичних видань, праці вітчизняних та зарубіжних науковців, статистичні дані вітчизняних підприємств, що представлені на ринку інформаційних технологій.

Результати дослідження. Аналіз існуючих джерел, дозволяє визначити причину виникнення, розвитку i подальшого масштабування діяльності стартапів. Головним поштовхом до виникнення такої бізнес-моделі як стартап, називають передбачуваність дій та інертність великих корпорацій, що успішно функціонують на ринку з уже існуючими товарами (послугами), в той час, як розробка, створення і впровадження інноваційних продуктів займає багато часу через складність існуючих організаційних структур. Внаслідок чого, стартапи, завдяки мобільності 3 точки зору втілення нових ідей є більш ефективними.

За визначенням Стіва Бланка, стартап - це тимчасова структура, яка займається пошуком відновлювальної, прибуткової і масштабованої бізнесмоделі [1]. 
На думку автора, коли компанія знаходить свої ринки збуту, можливість на них заробляти та починає рости, інноваційний бізнес-проект втрачає ознаки стартапу.

Від початку формування ідеї до виходу інноваційного продукту на ринок стартап проходить декілька етапів розвитку. Кожен вчений по-своєму трактує кількість та послідовність етапів розвитку, які проходить стартап у власній діяльності. Проаналізуємо основні підходи, що використовуються вченими та бізнес-практиками до визначення етапів стартап-проектів:

- Ідея - виділення етапів реалізації проекту - підготовка технічного завдання - реалізація ядра стартапу - розвиток - модернізація [2];

- Ідея - інкубатор - акселератор - вихід на ринок [3];

- Зародження - становлення - ранній розвиток - розширення - зрілість [20];

- Посів - запуск - зростання - розширення - вихід [4];

- Ідея - команда - ринок - концепція- технічне завдання - прототип тестування - альфа-версія - закрита бета-версія - публічна бета-версія запуск - пошук інвесторів [5].

Таблиия 1

Етапи розвитку стартапів та їх специфіка

Джерело: систематизовано на основі [2],[3],[4],[5]

\begin{tabular}{|c|c|c|}
\hline Автор & Етапи & Специфіка \\
\hline \multirow[t]{6}{*}{$\begin{array}{l}\text { Студія } \quad \text { «Startup } \\
\text { Creation» }\end{array}$} & Ідея & $\begin{array}{l}\text { Відбувається обговорення концепції } \\
\text { проекту в цілому, розуміння його суті і } \\
\text { перспектив розвитку, виконується } \\
\text { оцінка вартості та термінів реалізації } \\
\text { проекту }\end{array}$ \\
\hline & $\begin{array}{l}\text { Виділення етапів реалізації } \\
\text { проекту }\end{array}$ & $\begin{array}{l}\text { Розбиття проекту на окремі етапи, в } \\
\text { кожному з яких розробниками будуть } \\
\text { виконуватись технічні завдання(Т3). }\end{array}$ \\
\hline & $\begin{array}{l}\text { Підготовка } \\
\text { завдання }\end{array}$ & $\begin{array}{lrrr}\text { Підготовка } & \text { T3 } & \text { на } & \text { перший етап - } \\
\text { розроблене } & \text { T3 } & \text { узгоджується } \\
\text { розробниками } & \text { 3 автором проекту, який } \\
\text { 3годом вносить в нього свої корективи. }\end{array}$ \\
\hline & Реалізація ядра стартапу & $\begin{array}{l}\text { 3апуск проекту максимально швидко та } \\
\text { у спрощеному вигляді(так як його } \\
\text { потрібно буде оптимізувати до } \\
\text { споживача). Після його завершення } \\
\text { проект вже починає працювати }\end{array}$ \\
\hline & Розвиток & $\begin{array}{l}\text { Проект розвивається і нарощується в } \\
\text { реальному часі, враховуючи побажання } \\
\text { користувачів і автора, поки не буде } \\
\text { повністю реалізована вся його } \\
\text { концепція в рамках вихідної ідеї }\end{array}$ \\
\hline & Модернізація & $\begin{array}{l}\text { Процес доопрацювання i адаптації } \\
\text { продукту }\end{array}$ \\
\hline Олександр Кардаков & Ідея & $\begin{array}{l}\text { Початок будь-якого стартапу. На } \\
\text { даному етапі проводиться початкове } \\
\text { фінансування, яке здійснюєтья } \\
\text { родичами та друзями, можливо } \\
\text { бізнесменами, які підтримали } \\
\text { початкову ідею. }\end{array}$ \\
\hline
\end{tabular}




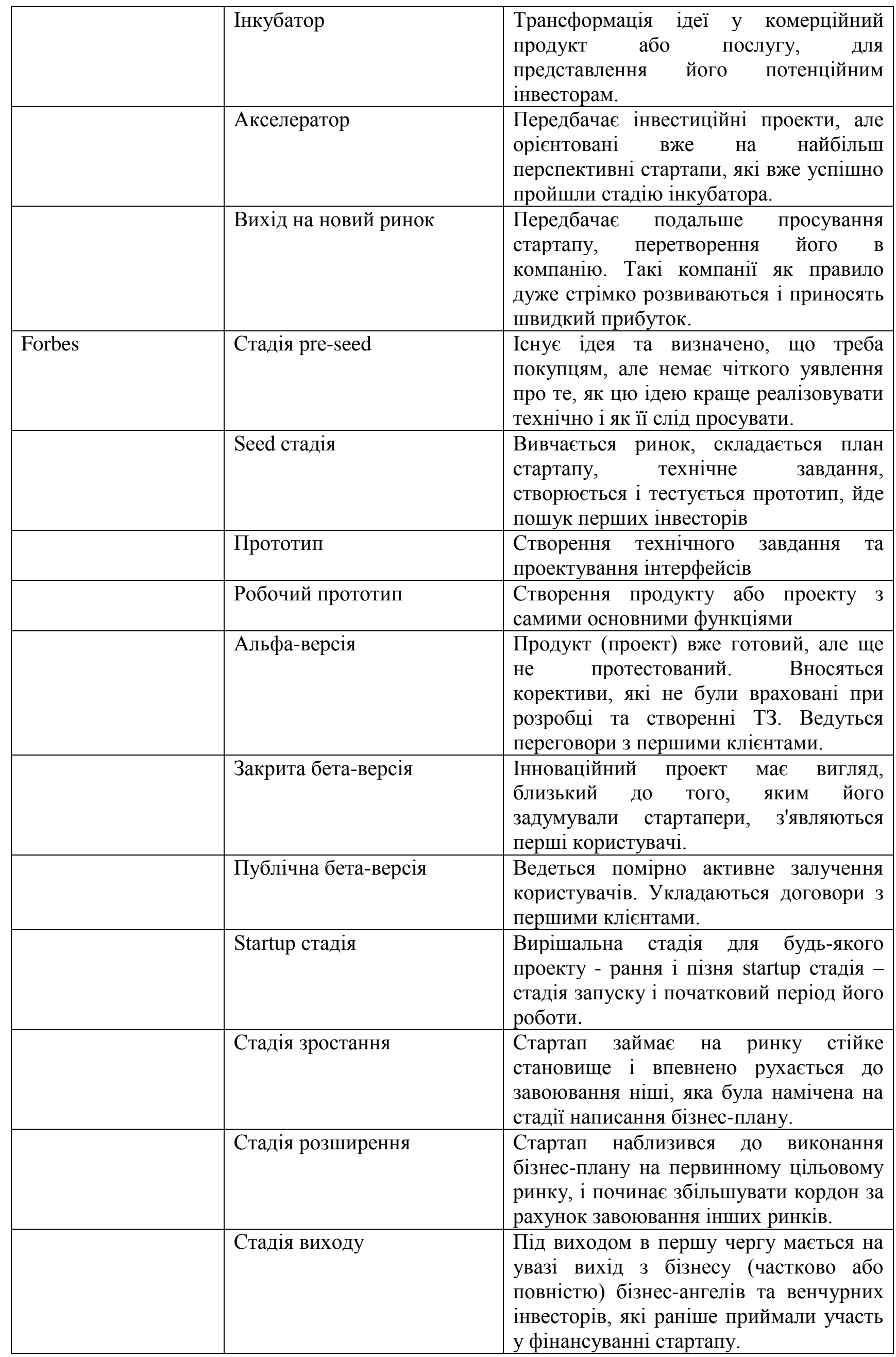


Варто зазначити, що вище перераховані етапи стартап-проектів будуть коригуватись в залежності від специфіки стартапу. Проте, уже починаючи із першого етапу розвитку стартапів необхідно вибудувати послідовність маркетингових дій стартап-проекту. Враховуючи індивідуальність стартапів, спробуємо визначити послідовність маркетингових дій починаючи від створення ідеї нового продукту до його виходу на ринок.

Стартап може виникати як самостійний проект, так і всередині великих корпорацій. Більшість стартапів відносяться до незалежних, оскільки вони створюються і розробляють новий продукт поза межами існуючих компаній (хоча на подальших етапах розвитку стартапи можуть стати підрозділами інших компаній). Разом 3 тим, намагаючись підвищити власний інноваційний потенціал, великі компанії створюють внутрішні організаційні структури, або афілійовані стартапи, діяльність яких спрямована на розробку важливого для компанії інноваційного продукту.

Переважна більшість авторів, що займались дослідженням діяльності стартапів і їх етапів розвитку розглядають стартап як окремий бізнес, що починає працювати з нуля, від зародження ідеї до виходу товару(послуги) на ринок, проте не вивченою $\epsilon$ специфіка саме тих стартап-проектів, що $\epsilon$ інтегрованими в бізнес-модель великих корпорацій.

Спираючись на класифікацію стартапів, важливо виділити значну відмінність між незалежними та афілійованими стартап-проектами. Послідовність стадій стартапів може збігатись, проте особливості кожної із стадій матимуть значні відмінності.

На маркетингові дії в обох випадках впливають неодмінні складові стартапу. Ядром створення нового стартап-проекту є новаторська ідея, що не має матеріального втілення, а існує на папері або на словах. Від рівня ідеї залежить життєздатність стартапу, чим вона унікальніша, заснована на фундаментальних дослідженнях або обумовлена потребами практики, тим довший життєвий цикл новоствореного продукту, а відповідно i його економічна ефективність. Прикладами стартап-проектів, створення яких базувалось на потребах споживачів, можна назвати наступні бренди: соціальні мережі Linkedin i Facebook; відеохостінги YouTube i Vimeo.

Наступною складовою $є$ інтелектуальні ресурси, тобто наявність команди, цілеспрямованих професіоналів, що будуть працювати над втіленням ідеї в життя. В іiі обов'язки входить генерація ідей, їх реалізація в інноваційний продукт, розробка стратегії розвитку стартапу, планування, ефективне управління, забезпечення необхідними ресурсами тощо.

По-третє, стартап - це своєчасне залучення необхідних ресурсів. При цьому варто зауважити, що на кожному етапі реалізації ідеї, необхідно чітко визначити інвестиційну політику, направлену на максимізацію прибутку. Головною проблемою зазвичай стають зайво залучені кошти на початку розробки ідеї, які можуть спричинити проблеми в команді, втрату мотивації та ïx нестачу в кінці для забезпечення ефективного маркетингу. Тому необхідне поступове планомірне виважене інвестування кожного етапу інноваційного проекту. 
Четвертою складовою стартапу $є$ маркетинг інновацій, який слід одночасно розглядати: "як концепцію ринкової діяльності підприємства (філософію бізнесу), коли в змінах вбачають джерело доходу; як аналітичний процес, що передбачає виявлення ринкових можливостей інноваційного розвитку; як засіб активного впливу на споживачів та цільовий ринок у цілому, що пов'язаний з виведенням та просуванням інновації на ринок; як функцію інноваційного менеджменту, спрямовану на виявлення можливих напрямків інноваційної діяльності, їх матеріалізацію і комерціалізацію" [7].

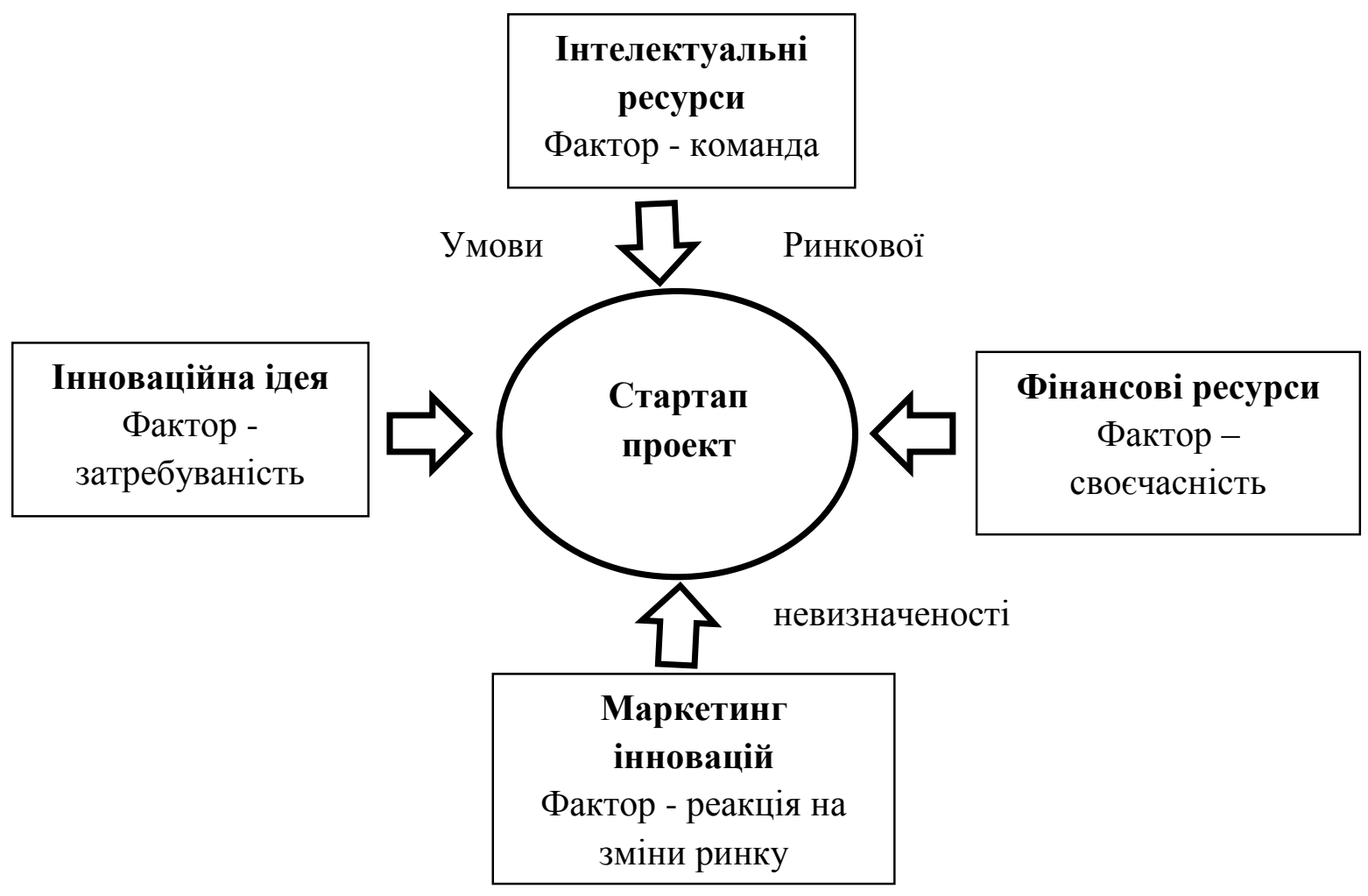

Рис. 1 Складові стартап-проекту

Джерело: складено на основі [1],[2],[7]

Проведений аналіз дозволяє визначити інновації, фінансові ресурси, команду та маркетинг інновацій як неодмінні складову як незалежного, так i афілійованого стартап-проекту.

Розглянемо маркетингові дії в афілійованому та незалежному стартапах на кожному із етапів, розроблених нами на основі аналізу приведених вище стадій діяльності стартапів, при цьому будемо враховувати специфіку кожної зі складових.

Початком незалежного стартапу є виникнення ідеї, яка формується у більшості випадків спонтанно, вона виникає в голові засновника. Логічним завершенням $є$ перетворення на «повноцінну компанію» або продаж проекту великій корпорації.

Зобразимо етапи незалежного та афілійованого стартапів на рисунках 3,4 та визначимо дії, які необхідно виконати на кожному із зазначених етапів, а також суб'єкти та інститути, що впливатимуть на діяльність проекту в процесі його реалізації. 


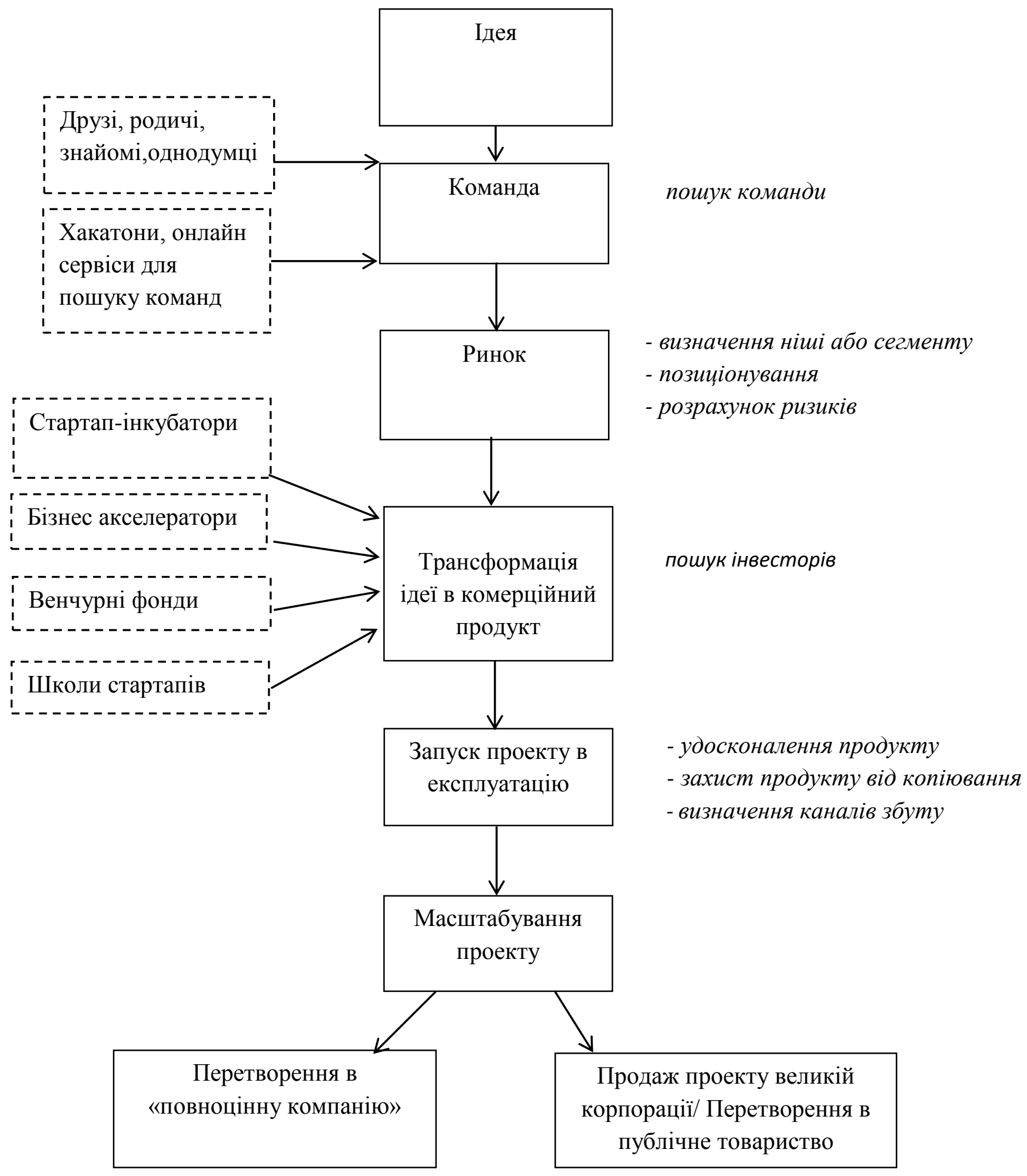

Рис. 2 Бізнес-модель незалежного стартапу

Джерело: авторська розробка

Афілійований же стартап у своєму розвитку проходить інші етапи, починаючи із першого - це не ідея, а усвідомлення необхідності створення стартапу в рамках компанії, завершення - вбудовування стартапу в бізнесмодель компанії. 


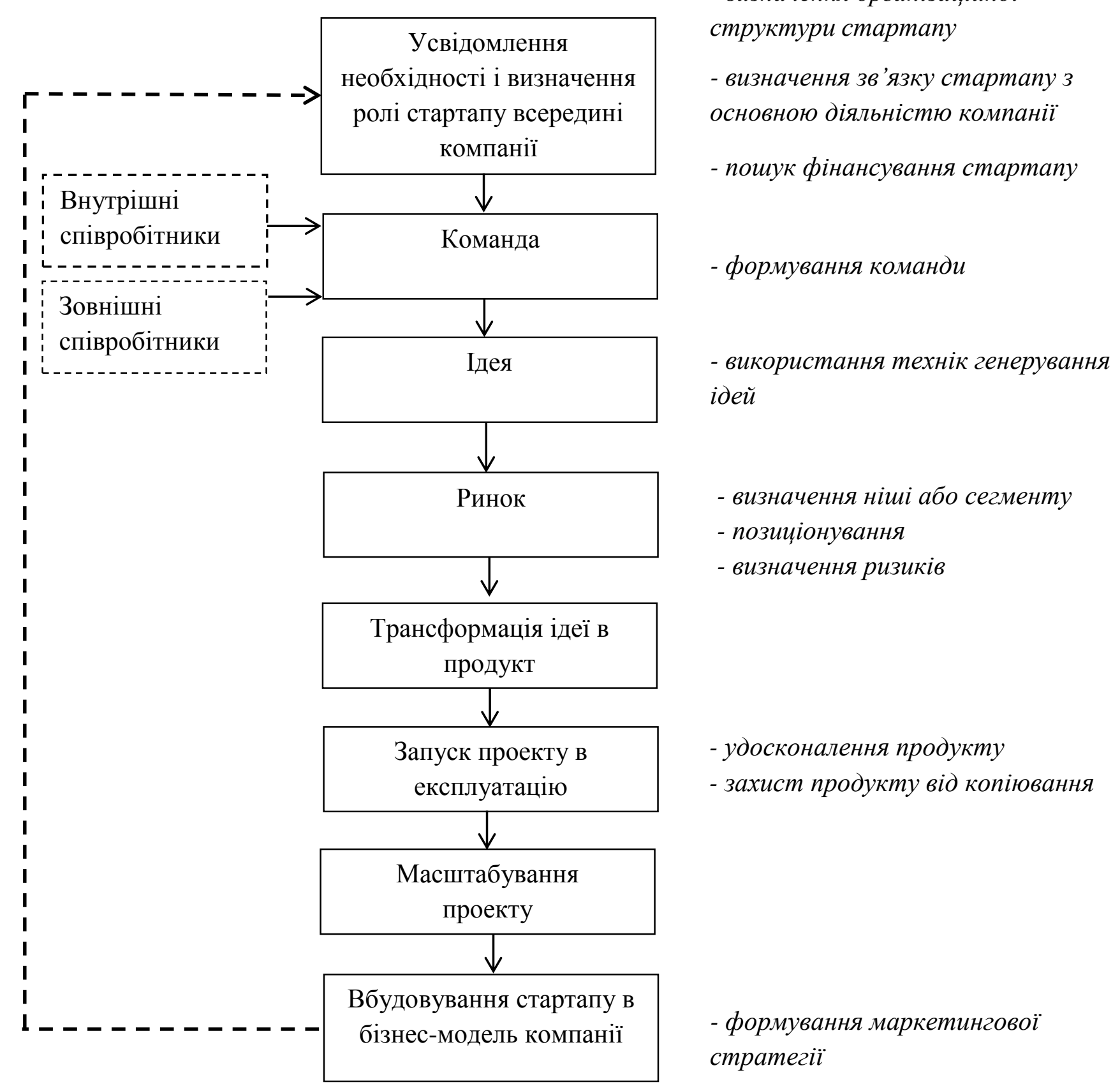

- визначення організаціийної

структури стартапу

- визначення зв'язку стартапу з

- пошук фінансування стартапу

- формування команди

- використання технік генерування ideŭ

- визначення ніші або сегменту

- позичіонування

- визначення ризиків

Рис. 3. Бізнес-модель афілійованого стартапу

Джерело: авторська розробка

Отже, після формування моделей розвитку незалежного та афілійованого стартапів ми бачимо відмінність як в послідовності етапів, інститутів та осіб задіяних в розвитку стартапів, а отже існує значна відмінність в маркетингових діях, які необхідно застосовувати. Визначимо та порівняємо етапи розвитку стартапів, їх характеристики та маркетингові дії в таблиці 2. 
Маркетингові дії в незалежних та афілійованих стартапах

Джерело: складено автором

\begin{tabular}{|c|c|c|}
\hline Ознака & Незалежний стартап & Афілійований стартап \\
\hline $\begin{array}{l}\text { Спосіб виникнення ідеї } \\
\text { стартапу }\end{array}$ & Відбувається стихійно & $\begin{array}{l}\text { Формування креативних груп } 3 \\
\text { внутрішніх співробітників } \\
\text { компанії та залучення сторонніх } \\
\text { спеціалістів, які використовують } \\
\text { методи генерації ідей (мозковий } \\
\text { штурм, морфологічний метод, } \\
\text { метод синектики тощо) }\end{array}$ \\
\hline Формування команди & $\begin{array}{l}\text { Залучення до стартапу друзів, } \\
\text { знайомих, } \\
\text { однодумців. }\end{array}$ & $\begin{array}{ll}\text { Відбір внутрішніх } & \text { кадрів та } \\
\text { залучення } & \text { зовнішніх } \\
\text { спеціалістів. } & \end{array}$ \\
\hline Джерела фінансування & \begin{tabular}{lcr} 
Цільова & аудиторія (ЦА) & - \\
інвестори. & & \\
Завдання & маркетолога & - \\
залучення & інвестицій & На \\
початкових & етапах & - \\
самофінансування. & \\
На етапі трансформації ідеї в \\
повноцінний & продукт & - \\
венчурні & \multicolumn{2}{c}{ фонди, } \\
краудфандинг, \\
субосес-ангели,
\end{tabular} & $\begin{array}{l}\text { ЦА - акціонери та керівництво } \\
\text { компанії. } \\
\text { Інвестування відбувається } \\
\text { коштами компанії. } \\
\text { Завдання маркетолога } \\
\text { визначення в портфелі бізнесів } \\
\text { компанії «дійної корови», за } \\
\text { рахунок якої покриватимуться } \\
\text { витрати на R\&D стартапу. }\end{array}$ \\
\hline $\begin{array}{l}\text { Траєкторія } \\
\text { розвитку }\end{array}$ & 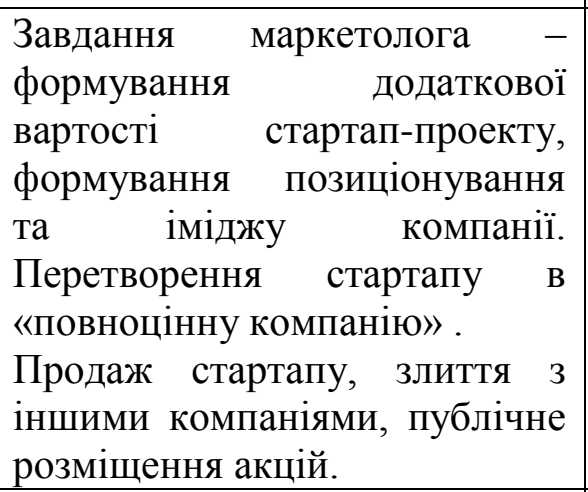 & $\begin{array}{lll}\text { Завдання } & \text { маркетолога } \\
\text { вбудовування } & \text { стартап-проекту в } \\
\text { модель } & \text { бізнесу }\end{array}$ \\
\hline $\begin{array}{l}\text { Запуск проекту } \\
\text { експлуатацію }\end{array}$ & $\begin{array}{l}\text { ЦА - ранні послідовники } \\
\text { Завдання } \quad \text { маркетолога - } \\
\text { визначення ціни, визначення } \\
\text { каналів збуту, просування } \\
\begin{array}{l}\text { продукту, } \\
\text { зворотної отримання } \\
\text { користувачів }\end{array}\end{array}$ & 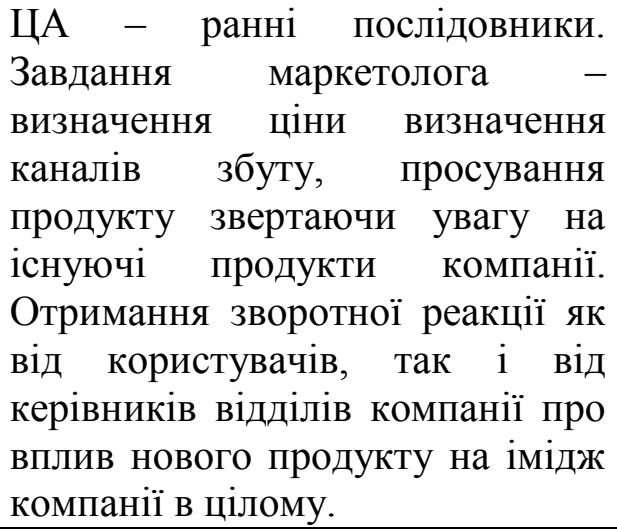 \\
\hline
\end{tabular}

Варто зазначити, що всі стартапи, незалежно від того чи вони «гаражні», чи створені всередині певної компанії, діють в умовах повної ринкової невизначеності. Це означає, що стандартні методи формування маркетингової стратегії тут не діють, проте це не привід для компанії діяти хаотично. 
Як для афілійованих так і для незалежних стартапів варто чітко розуміти цільові аудиторії на кожному із етапів розвитку, так як це не лише кінцевий споживач, а й фінансові інститути. При розробці продукту необхідно мати на увазі, що ЦА - це переважна більшість, проте при виведенні продукту на ринок - це ранні послідовники. Ще одним фактором, який часто упускається науковцями є захист продукту від копіювання. Так як стартапи випускають здебільшого інноваційні товари (послуги), важливо при запуску інновації на ринок мати всі необхідні документи для застереження недобросовісної конкуренції.

Висновок. Діяльність та розвиток стартапів в умовах ринкової невизначеності створює нові напрямки маркетингової діяльності. Традиційні маркетингові стратегії повинні адаптуватись до кожного із етапів розвитку стартапів, відповідно до специфіки кожного проекту.

Важливо враховувати, що на окремих етапах розвитку стартапу маркетингові цілі, цільові аудиторії і відповідно маркетингові дії будуть різними, вони повинні коригуватись з урахуванням найменших змін в умовах діяльності стартапів.

\section{Література:}

1. Бланк С. Стартап: настольная книга основателя / С. Бланк, Б. Дорф.- М. : Альпина Паблишер, 2013. - 616 с.

2. Студія «Startup Creation» - [Електронний ресурс] - Режим доступу: http://startupcreation.net.

3. Журнал «Forbes» - [Електронний ресурс] - Режим доступу: http://forbes.ru.

4. Этапы развития стартапов - [Електронний ресурс] - Режим доступу: http://startuphouse.ru/stati-pro-startapy/link/etapy-razvitiya-startapov.

5. Что такое стартап - [Електронний ресурс] - Режим доступу: http://www.temabiz.com/terminy/chto-takoe-startap.html.

6. От идеи к реализации: 12 этапов проектирования стартапа - [Електронний ресурс] Режим доступу: https://kontur.ru/articles/1493.

7. Content marketing innovation in the enterprise - [Електронний ресурс] - Режим доступу: http://www.pdaa.edu.ua/sites/default/files/nppdaa/4.1/146.pdf 